\begin{tabular}{|l|l|l||}
\hline \multicolumn{2}{|c|}{ PublisherInfo } \\
\hline \hline PublisherName & $:$ & BioMed Central \\
\hline \hline PublisherLocation & $:$ & London \\
\hline \hline PublisherImprintName & $:$ & BioMed Central \\
\hline \hline
\end{tabular}

\title{
Modified primers
}

\begin{tabular}{|l|l|l||}
\hline \multicolumn{2}{|c|}{ ArticleInfo } \\
\hline \hline ArticleID & $:$ & 4518 \\
\hline \hline ArticleDOI & $:$ & $10.1186 /$ gb-spotlight-20020701-01 \\
\hline \hline ArticleCitationID & $:$ & spotlight-20020701-01 \\
\hline \hline ArticleSequenceNumber & $:$ & 184 \\
\hline \hline ArticleCategory & $:$ & Research news \\
\hline ArticleFirstPage & $:$ & 1 \\
\hline \hline ArticleLastPage & $:$ & 2 \\
\hline \hline & & RegistrationDate : 2002-7-1 \\
\hline ArticleHistory & $:$ & OnlineDate \\
\hline \hline ArticleCopyright & $:$ & BioMed Central Ltd2002-7-1 \\
\hline \hline ArticleGrants & $:$ & \\
\hline \hline ArticleContext & $:$ & 130593311 \\
\hline \hline
\end{tabular}




\section{Jonathan B Weitzman}

Email: jonathanweitzman@hotmail.com

A limiting aspect of microarray experiments is the efficient production of labelled cDNA probes from small amounts of starting material (typically over $20 \mu \mathrm{g}$ of total RNA is required). In the July issue of Nature Biotechnology, Xiang et al. describe a technique for efficient and inexpensive probe production using random hexamer oligonucleotide primers that have been modified with free amino groups at their 5' ends (Nature Biotechnology 2002, 20:738-742). This method allows for the generation of fluorescent probes for microarray hybridization using as little as $1 \mu \mathrm{g}$ of total RNA. They used random primers with $5^{\prime}$ amino C6dT (thymidine modified at the 5' position with an 8-9 carbon chain ending in a primary amine) and incorporated aminoallyl-dUTP during cDNA synthesis. The fluorescent dyes (Cy3 and Cy5) were then chemically added to the free amino groups. Xiang et al.used microarray experiments to demonstrate that their technique is more efficient than conventional labelling methods (using oligo-dT priming and direct incorporation of fluorescent bases) and can be easily used with $1 \mu \mathrm{g}$ of total RNA without loss of expression profiling results.

\section{References}

1. High-fidelity mRNA amplification for gene profiling.

2. Nature Biotechnology, [http://www.nature.com/nbt/] 